\title{
IAMJ
}

INTERNATIONAL

AYURVEDIC

MEDICAL JOURNAL

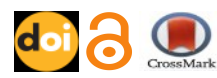

\section{CASE SERIES OF AYURVEDIC TREATMENT OF VALVULAR DEFECTS}

\author{
Sanyogita Surendra Shinde ${ }^{1}$ Minal S. Vaidya ${ }^{2}$
}

${ }^{1}$ MD Scholar Kayachikitsa Department; ${ }^{2} \mathrm{HOD}$, Prof. Kayachikitsa Department.

YMT Ayurvedic College, PG Institute and Charitable Trust, Kharghar, Navi Mumbai, Maharashtra, India

Email: sanyogitashinde25@gmail.com

\section{https://doi.org/10.46607/iamj0807332020}

(Published online: July 2020)

Open Access

(C) International Ayurvedic Medical Journal, India 2020

Article Received: 23/06/2020 - Peer Reviewed: 09/07/2020 - Accepted for Publication: 09/07/2020

Check for updates

\section{ABSTRACT}

Cardiovascular diseases (CVDs) are the number 1 cause of death globally, taking an estimated 17.9 million lives each year ${ }^{1}$. A case series of four patients is presented with differing results with the same drug as their treatment. 4 patients with valvular defects but with different underlying cause are discussed here. For the CVD patients were given purely Ayurvedic treatment along with their previous medicines, so as to see the result of the medicine. Baladya Ghrit a combination of drugs is chosen from Ayurvedic text commentary on Agnivesh Samhita by Acharya Chakrapanidutta. 4 patients were assessed to have valvular defects by 2 Decho, here attempt is made by using Baladya Ghrit orally. 4 patients with different histories, 3 of them show significant result, one patient did not show any change. Here a focus on Hridroga is made to understand the action of Baladya Ghrit on different patients. A question can be raised that if this drug did not work for that one patient, what is the reason and is there a scope of studying this topic further? A relevant, scientific study should be done to access the Hridroga with various aspects in Ayurvedic treatment given.

Keywords: Baladya Ghrut, Hrudroga, Valvular Disease, CVD,

\section{INTRODUCTION}

According to the latest report of World Health

Organization, CVD is the leading cause of death. And also $70 \%$ of premature deaths occur due to CVD. All the pathies are developing their own missiles to treat 
life threatening diseases like CVD. Ayueveda being the science of life have given us the opportunity to explore its wealth. A combination of 4 drugs blended with $G o-$ ghrita is chosen for the study. Hridroga being the leading cause of mortality and morbidity, is also the cause due to which there are numerous numbers of patients left with disabilities. Even if the patient is saved with vigorous treatment from this grave disease, it may leave its mark in the form of disability in the patient. Valvular defects are becoming common in the heart diseased patient. As fibrosis, sclerosis is termed to be irreversible according to Allopathy, an important step to access and prove the result of Ayurvedic drugs is taken in order to spotlight the need of Ayurveda in this direction.

Study Design- 4 patients from the OPD having valvular heart disease were included in the study. All patients were continued with treatment until there was symptomatic relief. The valvular defects were assessed before and after the study.

Material- Baladya Ghrut is used in all patients Consists of 5 components- Arjuna, Bala, Nagbala, Yashtimadhu, Go-ghrut.

\section{Methodology-}

Route- Oral.

Dose- $20 \mathrm{ml}$ twice daily.

Duration- until the patient is symptomatically relieved.

\section{Reports-}

Case 1: A male patient aged 77 arrived to the Opd of Kayachikitsa with complaints of dyspnea grade 2, Edema grade 2, lassitude grade 2, increased frequency and quantity of micturition and with profused sweating, since 2 weeks. Known case of DM type 2 and was on regular medicines. He had no history of surgical illness and a clear family history. 2D echo report before treatment stated-1) moderate concentric LVH noted, 2) LVEF- 58\%, 3) Grade 1 diastolic dysfunction, 4) All cardiac valves are sclerotic, mild Aortic regurgitation. 5) No pulmonary hypertension. 2D echo after treatment- 1) mild concentric LVH present, 2) All cardiac valves are normal, 3) LVEF$60 \%, 4)$ type 2 diastolic dysfunction present, 5) mild pulmonary hypertension present.
Here in this patient Kapha Bahulya is present. That indicates the Atirikta increase in Sheet Guna. As well as hypertrophy indicates that the heart is trying to maintain the pressure Balance, due to which the muscle increase in size. Bruhane Guru, according to this it states that anything that has to increase its strength it needs Guru Guna. In Tridoshas Kapha is only the Dosha which has Guru Guna, which indicates the change in musculature of Hrudaya is due to Guru Guna of Kapha. Sclerosis of all the valves is present in the report before the treatment. Sclerosis means stiffening, which is Kathinya cause by Dushta Kapha. If the valves are stiffened there will be some amount of regurgitation of blood in the ventricles. As the Pitta Dosha in the Hrudaya is disturbed the Ushna Guna of Pitta causes profused sweating in certain conditions. The Kapha which ensures that the hearts have proper energy to pump the blood continuously is Dushta, i.e. the Bala giving Kapha Dosha is Dushta causing decrease in force of contraction which leads to decrease in LVEF.

These aspects are considered while discussing the effect of drug given.

CASE 2: A 56-year-old male patient complaints dyspnea on exertion grade3, lassitude grade1, profused sweating and body ache. His reports before treatment revealed: 1) LVEF- 50\%, 2) mitral annular calcification, no other abnormality. The symptoms after treatment reduced except for the sweating. Reports after treatment show: 1) LVEF- 58\%,2) normal cardiac valves, no other abnormality.

CASE 3: A 51-year-old male patient presented with burning pain while walking, dyspnea and sweating came for treatment. Known case of hypertension. Family history- mother - DM AND HTN. History of nephrolithiasis twice is present. Reports suggested-1) degenerative affection of mitral valve, 2) mild MR, 3) LVEF- 60\%, 4) grade 1 diastolic dysfunction. Reports after treatment suggested: 1) normal mitral, aortic, tricuspid and pulmonary valves, 2) no MR, 3) LVEF$60 \%$, 4) GRADE 1 diastolic dysfunction, 5) concentric left ventricular hypertrophy. 
CASE 4: A 66-year-old male patient had complaints of dyspnea grade 2 and profused sweating all along the day. He is a known case of DM type 2. A clear surgical and familial history was given by the patient. His reports before treatment interpreted were: 1) all cardiac valves are morphologically sclerotic, 2) LVEF- 55\%, 3 ) grade 1 diastolic dysfunction. After the treatment patient that relief in dyspnea in 10 days but profused sweating did not come to normal. His reports suggested: 1) all cardiac valves morphologically sclerotic, 2) LVEF- 51\%, 3) grade 1 diastolic dysfunction.

RESULT - A combination of drugs consisting antiinflammatory, cardio-protective, antioxidant, reperfusion properties is Baladya Ghrit which show a positive result on fibrosis, sclerosis and degeneration of valves.

\section{DISCUSSION}

Baladya Ghrit comes under the chapter of Hridroga Chikitsa of compendium Chakradutta ${ }^{2}$. Acharya Chakradutta explained that this combination of drugs i.e. Arjuna Twak, Bala Mool, Nagbala mool and Yashtimadhu Mool should be blended in Go- ghrita according to the given procedure. This can be used in the diseases like Hridroga, Shoola, Kshata, Raktapitta, Kasa and Vaatrakta.

Fibrosis is defined as the thickening and scarring of connective tissue. Sclerosis is abnormal hardening or excessive resistance to change. Degeneration is the process of deterioration of tissue, tere may be loss of functional activity.

In this study a primary focus on the patients with Hridroga is done. Here Go-ghrita is used as a medium to enhance the properties of the drugs. Even if Hridroga emerges from Kaphaj Samprapti it effects Vaat. As the Vaat Dushti occurs the most important function of Hrudaya is impaired i.e. Vikshepana (propel the blood). This hamper the cardiac output which in turn decreases the ejection fraction of the left heart. Dushta Kapha may dominate the heart walls, septum and valves including pulmonary and aortic. Here valves are considered more as the effect of medicines is first seen on the valves. Sclerosis or fibrosis is an irreversible process according to Allopathic science. Here are some evidences that the sclerosis or fibrosis of heart valves can be reversed by Ayurvedic medicines. Details of the drugs in the compound is given below-

1) Go-ghrita ${ }^{3}$ : it is described as Madhura Vipaka, Sheeta Virya, Vaat, Pitta, Kapha Shamak, Vayasthapana, Guru, Balya, Ojo-vridhikara and Rasayan. Go-ghrit is Balya, its Balya, Guru and Snigdha properties is important for Hrudaya to maintain its Snigdhata and Sthairya which can be dominated due to continuous movement of Hrudaya by increased Ruksha Guna of Vayu. Kapha does this function but as there is vitiation of Kapha, it becomes Kathin, which cannot do its normal function. So here Balya, Snigdha and Guru properties of Go-ghrit are important to maintain the proper physiology of heart.

2) Arjuna - properties of Arjuna are it is Sheeta in Guna, Hridya, stabilizes Kapha and Pitta. Arjuna in all the Ayurvedic texts is mentioned as Hridya Dravya. It is also used by many Acharyas to treat Hridroga. Arjuna in Ashtang Sangraha is mentions as Bhagna Sandhaniya. It indicates the affinity of Arjuna towards the bones and cartilages. The most part of cardiac valves are made up of cartilage. This can show the correlation that Arjuna works on the cartilage inflammation during fibrotic plaque formation, so it is called Hridya by the Acharyas. Arjun by its Sheet Guna and Pittashamaka properties encounter the inflammation in the valves. Arjuna has a Ropana property which can explain its work on the annular fibrosis of the valves. It may also work on the vegetation of Rheumatic Fever as it is said to be Vishaghna in property. Arjuna is said to conquer Khapa Vyadhi, it indicates that it cures injuries in the lungs. This indicates that the same mechanism of Ropana and Vishaghna properties must take place in the heart valves. According to new searches Arjuna have the hypotensive, anti-atherogenic, antiinflammatory properties. So even if there is and circulatory defect at the base of the valves Arjuna has a positive effect on it. Arjuna over-all with-it properties have a good effect on the fibrosis, sclerosis of the valves. 
3) Bala and Nagbala ${ }^{5}$ - Bala and Nagbala in Bhavaprakasha are describes as Sheeta, Madhuraa, Bala, Snigdha and Grahi. They provide Poshana to the myocardium. As the Snigdha Guna is present in Bala and Nagbala the Balance the Kapha Dosha in Hrudaya. With its Madhura Rasa which is Pruthvi and Jala Mahabhut Prandhan balances the myocardium with the Parthiv Guna and the Rasa and Rakta with proper amount of Jala Mahabhuta. Here Jala Mahabhuta is more of the importance as to encounter the Kathin Guna of Kapha and Ushna Guna of Pitta.

4) Yashtimadhu ${ }^{6}$ - it is said to have Hima, Guru, Madhura, Balya, Susnigdha, Vaat, Pitta and Rakta balancing, Vranashoath, Vishaghna properties. Here new researchers have found out the reperfusion property of Yashtimadhu in ischemic patients. That means Yashtimadhu restores the blood supply by reperfusion at the site where there is less amount of blood supply. Here Vishaghna property of Yashtimadhu can be taken as inhibition of free oxygen radicles which activate the complement chain. It is well known for its anti-inflammatory properties and is useful to encounter the inflammation in the heart valves. Its Susnigdha property eliminates the excess of Ruksha Guna which causes Shoshana that can be related to degeneration. Here Yashtimadhu works with it all properties to restore the myocardial function.

Baladya Ghrit is also described to be used in the same diseases and Dosha conditions which are explain in each drug separately. So Baladya Ghrit works according to the Prakruti Sama Samvya method.

In the cases discussed above 4 patients have different valve conditions. A patient with all sclerotic valves is not recovered. According to this study this patient may need more vigorous treatment for longer duration. All the other patients show proper recovery in the heart valves.

In case 1 the patient recovered the heart valve with an increase in LVEF by $2 \%$. Diastolic dysfunction raised from grade 1 to 2 . There was no change in the LVH. In Case 2 the annular calcification of mitral valve was reversed to normal and a significant raise in LVEF by $8 \%$ was achieved.
In case 3 the patient had degenerative mitral valve with MR, grade 1 diastolic dysfunction and LVEF $60 \%$. The mitral valve was normalized, and all the other entities remained the same. It can be interpreted that treatment should be continued to see the results.

In case 4 the patient had all sclerotic valves before and after the study whit decrease in LVEF by $4 \%$. This should be taken into consideration that all the cardiac valves were sclerotic. Maybe even if the treatment was continued patient would deteriorate. Here a deep study on this topic should be encouraged so as to understand the limitation and the point to change the treatment.

\section{CONCLUSION}

1) Baladya Ghrit with its precious compound, hence, have a great effect on fibrosis, sclerosis and degeneration of heart valves.

2) Properties like Madhuraa, Snigdha, Guru, Balya, Susnigdha and Hima all encounter the pathology of the fibrosis by anti-inflammatory, antioxidant, and reperfusion properties of the drugs.

A further study for the different uses of Baladya Ghrit as Hridya must be done. As all the drugs in this combination are proved to be cardio protective, it must have enormous effects on other pathologies impairing the function of heart.

\section{REFERENCES}

1. https://www.who.int/news-room/fact-

Sheetas/detail/cardiovascular-diseases-(cvds)

20/06/2020, 12.10pm.

2. Dr. Indradev Tripathi, Acharya Ramanath Dwivedi, chakradutta Savimarsha vaidyaprabha hindivyakhopet, Chowkambha prkashana, Varanasi, pg 204, verse 31.

3. Prof. K.R. Srikantha Murthy, Bhavprakash of Bhavamishra, Chowkambha prakashana, reprint 2016, pg 470.

4. Prof. K.R. Srikantha Murthy, Bhavprakash of Bhavamishra, Chowkambha prakashana, reprint 2016, pg 297, verse 27.

5. Prof. K.R. Srikantha Murthy, Bhavprakash of Bhavamishra, Chowkambha prakashana, reprint 2016, pg 250, verse 144.

6. Prof. K.R.Srikantha Murthy, Bhavprakash of Bhavamishra, Chowkambha prakashana, reprint 2016, pg 181, verse146. 
7. Chanj-lin Zang, Mei-qi Zhang, Yun Zang, Hong-Xia $\mathrm{Xu}$, Jing-min Wang, GUi-peing An, et. al. Glycyrrihizin protects rats heart against ischemicreperfusion injury through blockade of HMGBI-

After treatment:
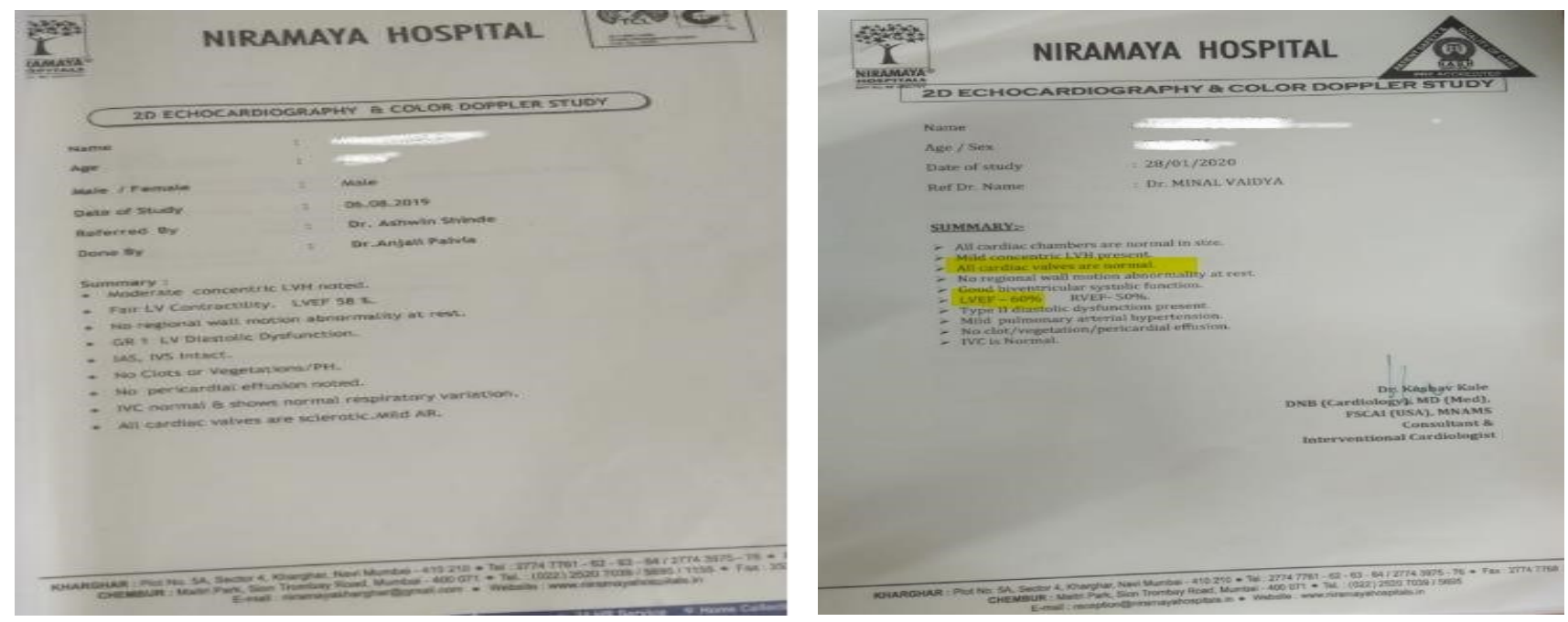

Case 2: Before treatment

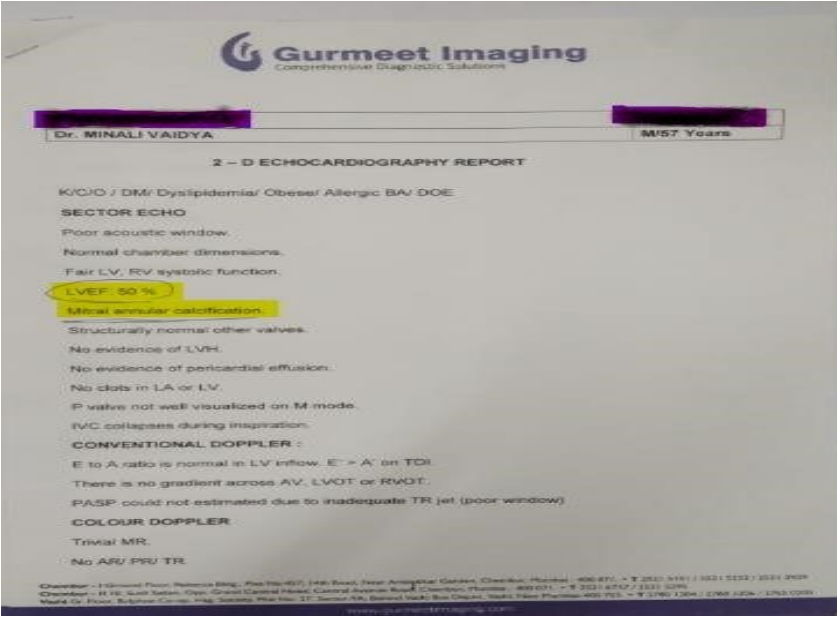

After treatment:

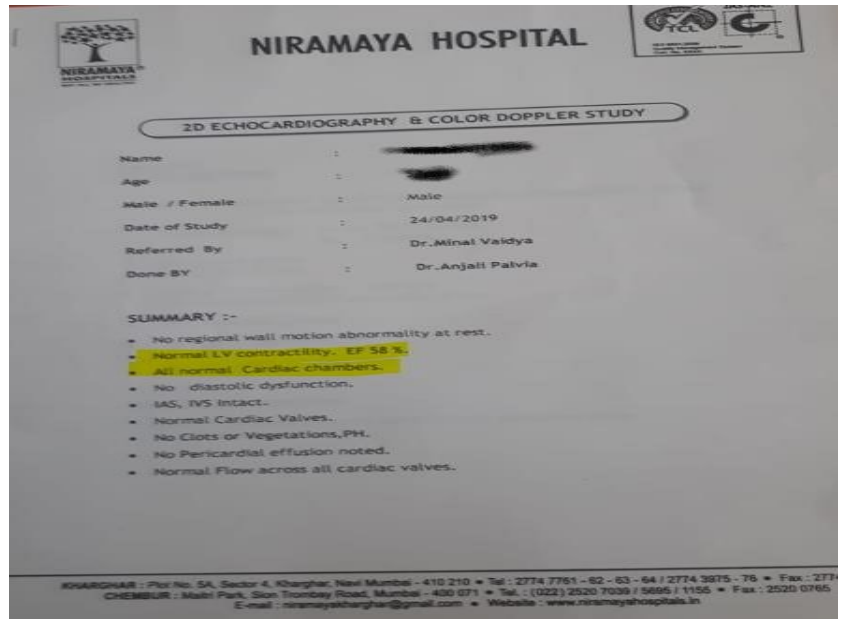

Case 3: Before treatment

After treatment:

dependent phosphor-JNK/Box pathway, APS, 2012 october 15, 33, pg 14771487.

8. Augustine Amalraj, Sreeraj Gopi, Medicinal properties of Terminalia Arjuna (Roxb.) wight \& Arn.: Areview, JTCM, 2017 January, issue 1, pg. 65-78. 


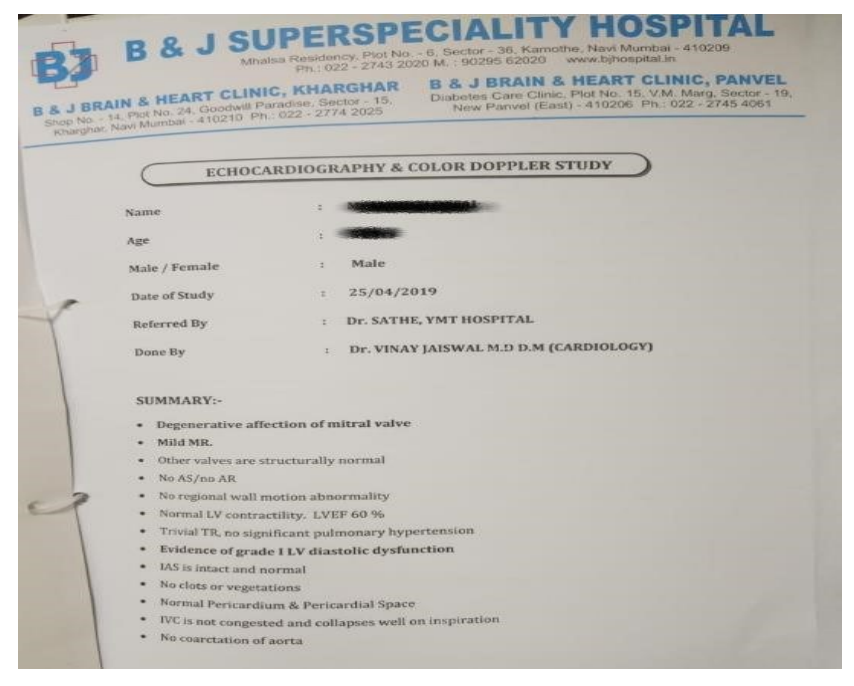

Case 4: Before treatment:

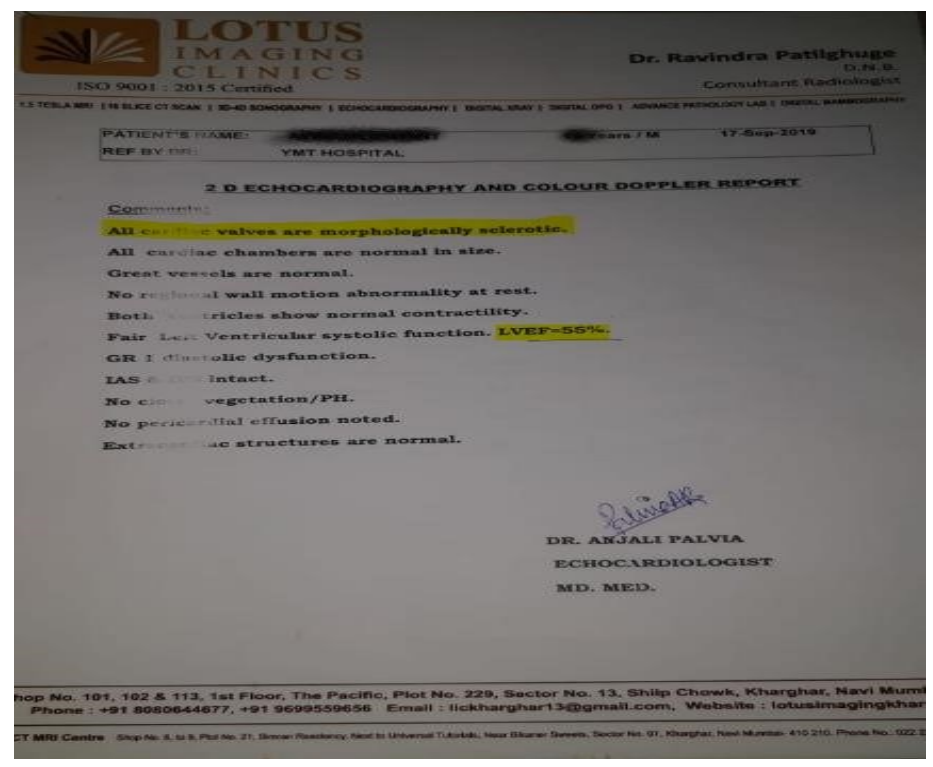

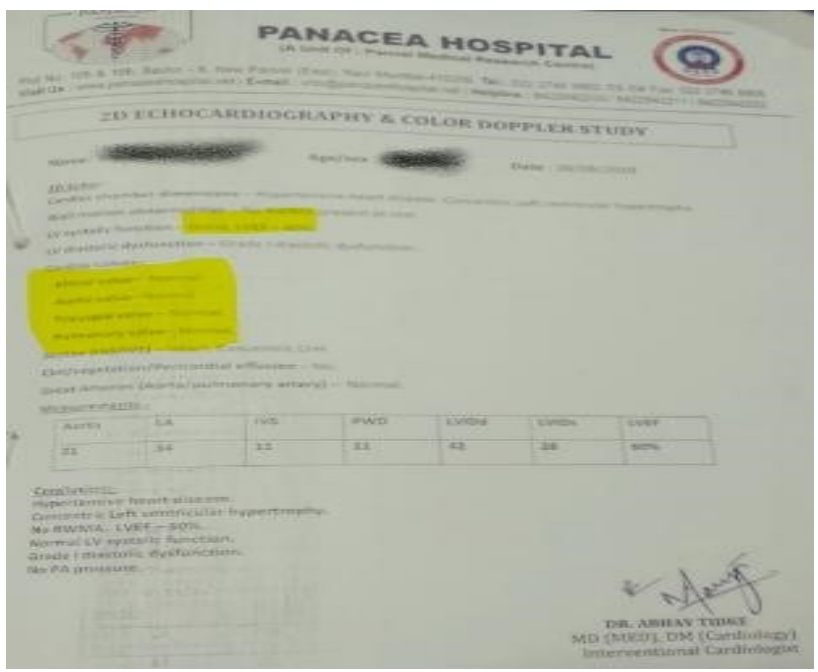

After treatment:

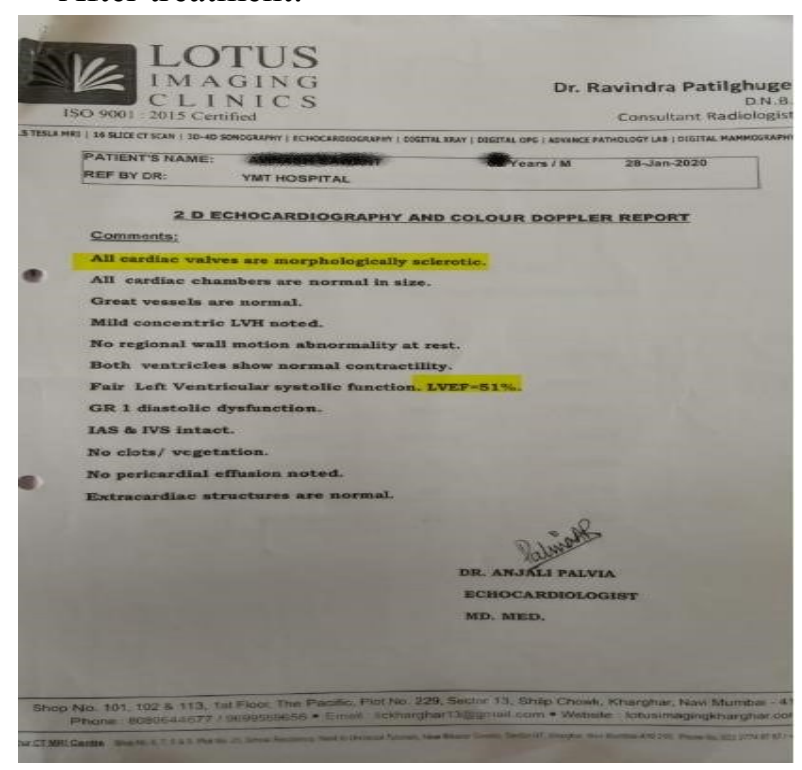

\section{Source of Support: Nil}

\section{Conflict of Interest: None Declared}

How to cite this URL: Sanyogita Surendra Shinde \& Minal S. Vaidya: Case Series Of Ayurvedic Treatment Of Valvular Defects. International Ayurvedic Medical Journal \{online\} 2020 \{cited July, 2020\} Available from: http://www.iamj.in/posts/images/upload/4019_4024.pdf 